\title{
Progress towards highly stable and lead-free perovskite solar cells
}

\author{
Muhazri Abd Mutalib ${ }^{1}$. Norasikin Ahmad Ludin ${ }^{1}$ (1) Nik Ahmad Aizudden Nik Ruzalman ${ }^{2}$. Vincent Barrioz ${ }^{2}$. \\ Suhaila Sepeai ${ }^{1} \cdot$ Mohd Asri Mat Teridi $^{1} \cdot$ Mohd Sukor Su'ait $^{1} \cdot$ Mohd Adib Ibrahim ${ }^{1} \cdot$ Kamaruzzaman Sopian $^{1}$
}

Received: 23 August 2017 / Accepted: 1 March 2018 / Published online: 28 March 2018

(c) The Author(s) 2018

\begin{abstract}
High-performance perovskite solar cells have attracted increased attention for photovoltaic applications and potentially replacing the predecessor generations. Nevertheless, the stability issues and the lead content has always been among the major concerns that barriers perovskite solar cells from commercialization. This review presents the discussion towards the inherent instability of perovskite solar cells and the development towards replacing lead with discussion towards their performance and challenges. The degradation of perovskite active layer would release toxic substance into the environment. The development towards low-toxic, lead-free and efficient perovskite solar cells is the key for a sustainable solar energy generation with the application of perovskite solar cells.
\end{abstract}

Keywords Perovskite solar cells $\cdot$ Lead-free perovskite $\cdot$ Moisture-stability $\cdot$ Sn perovskite $\cdot$ Power conversion efficiency

\section{Introduction}

The interest of power conversion from light source has been on the rise over the years as an alternative energy generation technology since it is considered as natural, renewable, clean, safe as well as free from negative side impacts to human and nature. Even though current photovoltaic market is dominated by first generation silicon solar cell by $80-90 \%$ with highest recorded efficiency at Standard Test Condition (STC) above 25\% [1, 2], second generation Thin Film solar cell is rapidly approaching behind at current highest efficiency based on STC positioning CIGS and CdTe based thin film at 22.6 and $22.1 \%$, respectively [3].

Even with the advantages of first generation solar cell, the production cost is still higher that the other generations and $50 \%$ of the cost is originated from the price of the silicon wafer itself [4]. In contrast to silicon solar cell, lesser material is needed to produce thin film solar cell and the

Norasikin Ahmad Ludin

sheekeen@ukm.edu.my

1 Solar Energy Research Institute (SERI), Universiti Kebangsaan Malaysia (UKM), 43600 Bangi, Selangor, Malaysia

2 Department of Physics and Electrical Engineering, Northumbria University, Ellison Building, Newcastle upon Tyne NE1 8ST, UK production of thin films does not require complicated processing steps as compared to silicon solar cell. The production cost is much lower and this is one of the main advantages for this technology to outrun the existing solar cell technology [5]. Currently, ongoing research for thin film absorber material is much focusing on CdTe solar cells considering these materials permits high-efficiency and stability [6]; however, due to the fact that limited availability and rising cost of Te with projected demand for PV module is high [7], a new material as an absorber layer is needed to replace these material.

From the concept of thin film, in 1991, Michael Graetzel introduced the architecture of Dye Sensitized Solar Cell (DSSC) and it is categorized into third generation solar cell. Similar to the thin film solar cell, DSSC also possess several advantages that is closing the gaps between existing silicon solar cell technology such as low-manufacturing cost, eco-friendliness, availability, and simple manufacturing requirements. Other than the architecture of 'Dye' and 'Sensitizer' in DSSC, the difference between DSSC and thin film solar cell is the involvement of redox couple to assist the light-power conversion. While there are researches focusing on the stability of DSSC [8], other research groups are also focusing on the fabrication technique [9, 10], material for counter electrode [11, 12] and alternative material for the sensitizer to improve its 
explicitly, such as $\mathrm{CdS}, \mathrm{Ag}_{2} \mathrm{~S}, \mathrm{CdTe}, \mathrm{CdHgTe}, \mathrm{InAs}, \mathrm{PbS}$, $\mathrm{TiO}_{2}, \mathrm{ZnO}$ and carbon-based species [13].

The incorporation of perovskite material into DSSC as the sensitizer layer marks the beginning of Perovskite Solar Cell (PSC) advancement and it is a promising technology for future power generation from solar irradiation. PSC has attracted interest from many researchers due to its ease of fabrication steps, low-cost starting material, high-efficiency and able to outperform DSSC as well as conventional solar cells. Figure 1a shows the introduction of perovskite material in DSSC where it functions as a replacement for the dye sensitizer for the mesoporous $\mathrm{TiO} 2$ layer. In this type of architecture, the working concept is the same with normal DSSC where it is by redox couple and recorded efficiency is 9.7\% [14]. The incorporation of perovskite material in DSSC is almost similar to the concept of quantum dot (QD) solar cell [15].

Previous study had fabricated a non-sensitized PSC using mesoporous $\mathrm{Al}_{2} \mathrm{O}_{3}$ to support the perovskite layer [16]. The unique criteria of perovskite material can be observed in this study with the solar cell structure as in Fig. $1 \mathrm{~b}$, where it was proven that the electron was not injected into the $\mathrm{Al}_{2} \mathrm{O}_{3}$ layer, instead it is transported through the perovskite layer to the electrode layer. This is due to the higher electron mobility in perovskite compared to $\mathrm{Al}_{2} \mathrm{O}_{3}$ layer, at 25 and $7.5 \mathrm{~cm}^{2} \mathrm{~V}^{-1} \mathrm{~S}^{-1}$, respectively [16]. Based on this observation, two preliminary conclusions were outlined; electron transportation is possible in the perovskite material and it is not necessary to include electron transport material (ETM) in PSC [14]. This is where the cell structure of PSC leads to planar perovskite solar cells as in Fig. 1d. The planar design allowed the PSC to be fabricated without the $\mathrm{TiO}_{2}$ layers which requires annealing at high temperature. Nevertheless, some research group still employs the mesoscopic perovskite solar cells (Fig. 1c) due to the reported disadvantages of planar architecture which includes high-density of trap states and more severe hysteresis phenomenon compared to the mesoscopic perovskite solar cells [17].
Planar architecture PSC was then further developed into inverted structure. In inverted structure, we would observe the order of electrodes is flipped into $p$ - $i$ - $n$ junction and hole transport layer (HTM) is deposited before the perovskite material [18]. It was reported that the inverted design had allowed facile and cost-effective of fabrication [18]. This review, however, will be focusing towards the mesoporous PSC and planar PSC. Planar PSC can be processed at low temperature, due to the absence of high temperature processed $\mathrm{TiO}_{2}$, has been able to achieve high power conversion efficiency close to mesoporous PSC [19, 20]. Nevertheless, previous study had overcome the high temperature processed $\mathrm{TiO}_{2}$ by employing atomic layer deposition of $\mathrm{TiO}_{2}$ layers with low temperature plasma [21]. This development had enable the fabrication of PSC devices on a flexible plastic substrate and showed that mesoporous PSC can possibly be produced without the high temperature annealing process.

Despite the advantages of PSC, there are several drawbacks of this architecture. One of the most concerning is the cell's efficiency and stability. Since solar cell is considered as a waste of electrical and electronic equipment [22], it is important to consider stability issues to commercialize this technology. Very few stability studies have been conducted to date [23]. It can be shown directly from the graph obtained from NREL where researchers worldwide are trying to increase the efficiency of PSC from 3.8\% (2009-Toin University) to 21.1\% [3, 24]. More and more researches is ongoing as this paper was completed. However, this yearly highest recorded efficiency for PSC that is recognized by NREL is so far involves lead-based material. The first recorded PSC with power conversion efficiency (PCE) at 3.8\% is lead-based material [24]. As for KRICT in their 2013, 2014, and 2015 record, they are using leadbased Perovskite material [3], the only difference between these record-breaking PSC is the fabrication process. Details about this fabrication process are yet to be published by them. Research by Oxford University in 2013 is also leadbased material. Research that incorporates lead-based PSC have been shown by many as shown in Table 1, this table
Fig. 1 Incorporation of perovskite material from the earliest cell design (a DSSC) to existing design (d Perovskite solar cell) [14] (a)



(b)

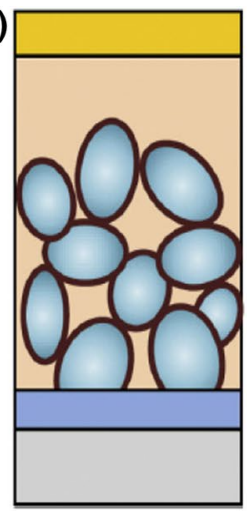

(c)

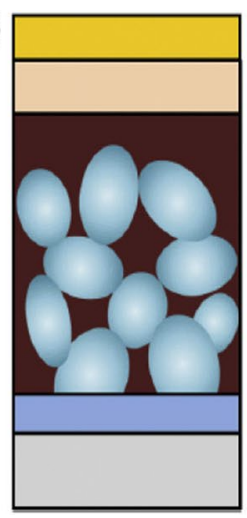

(d)

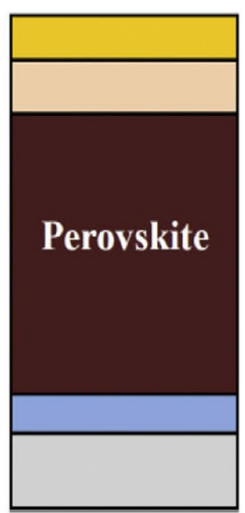




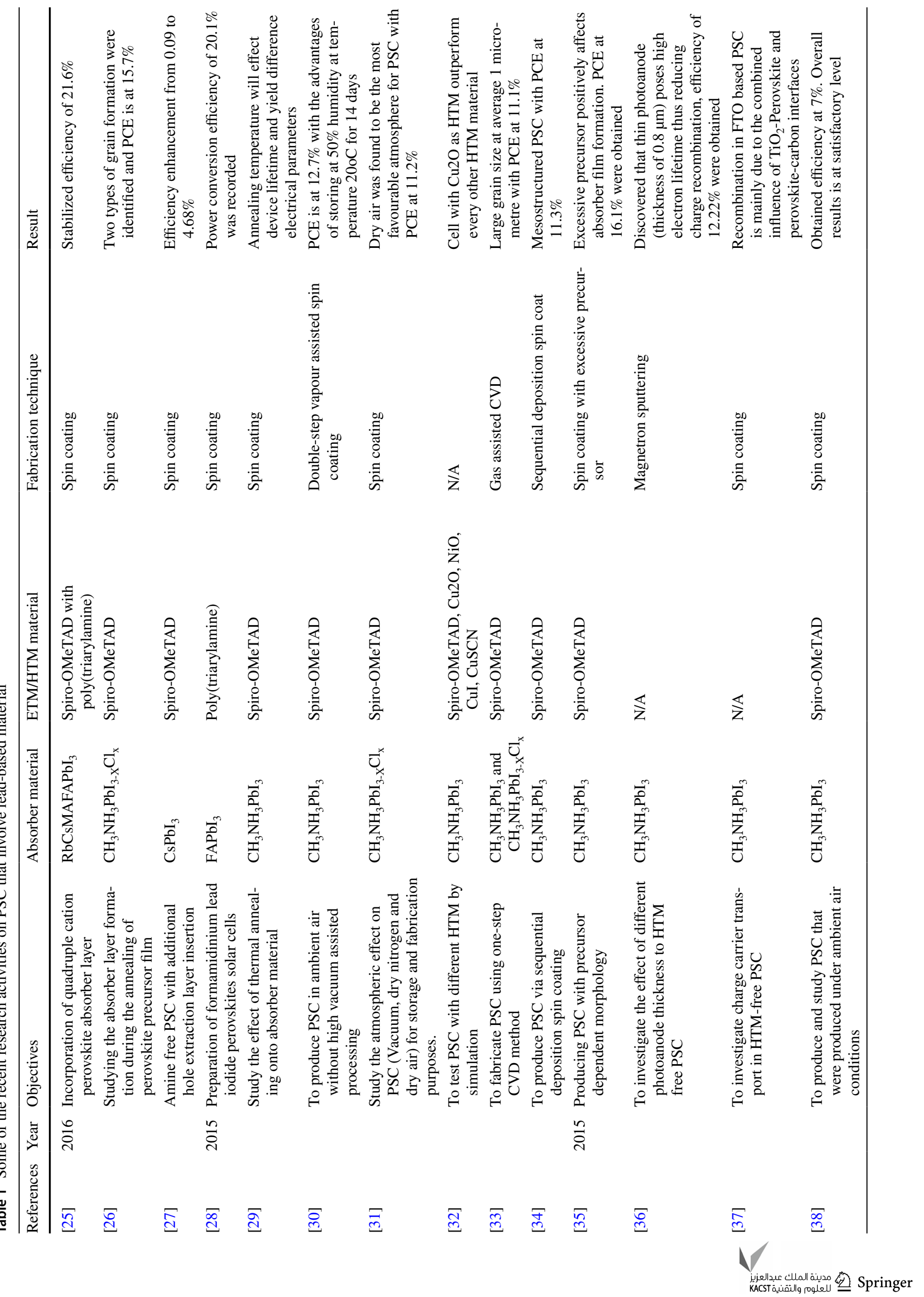




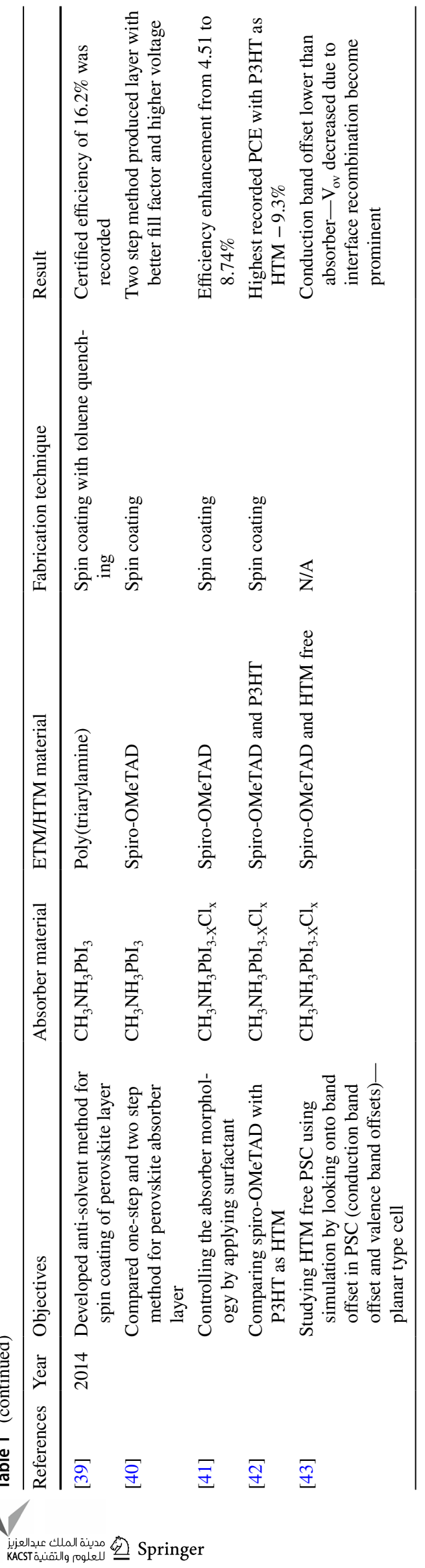

eventually shows the current prospects of PSC research and it focus on the absorber material and some other parts in PSC were also considered. Their efficiency was at very satisfying level, but seldom address the issue of environmental impact that can be caused by the device.

The toxicity issues due to lead had also been a major obstacle to commercial application of perovskite solar cells. There are complications associated with the environment and human health when lead-based materials are used in perovskite solar cells. Human exposure to lead can cause brain malfunction, premature infants and low birth rate, circulatory system damage and kidneys malfunctioning. Not only to humans, lead can also cause negative impacts to the environment as well as aquatic life. Current situations have urged researchers to focus on obtaining record-breaking efficiency of PSC, but without seriously addressing the environmental impact that lead can cause. Lead-free PSC will be undeniably crucial if this technology is to be commercialized and to compete with existing PV technologies.

As current publications have address the toxicity issue of lead [23, 44-47], increasing number of researchers have attempt to find suitable replacement of lead in PSC [48-50]. Most notably, Sn-based perovskite had been viewed as the most suitable replacement due to its similar chemical nature to $\mathrm{Pb}$ as group 14 metal. Nevertheless, the stability issues of Sn with self-doping had limits the development of Snbased perovskite [51]. This issue can potentially be managed by adding $\mathrm{SnF}_{2}$ as inhibitor towards the formation of $\mathrm{Sn} 4+$ [51]. Additionally, encapsulation also improves the overall device stability which had been proven to be able to maintain $98 \%$ of its power conversion efficiency over 100 days. Thus, there are huge potential for the development of other materials as replacement for the highly toxic lead to produce lead-free perovskite solar cells with high-efficiency.

\section{Cell structure and working mechanism of PSC}

The common working principle of any existing solar cell is energy absorption from light source, electron-hole separation, charge collection and electron-hole recombination. Although the exact working principle of PSC is not very well understood at the time being $[46,50]$, the most simple and reliable explanation is as described by Park et al. in Fig. 2 [44]. Photon with enough energy is emitted onto the PSC surface and its energy is absorbed by the absorber. Electron-hole pair will be produced due to the difference in electric field applied by the electrodes, the electron and hole will be attracted, thus movement of the electron will produce electricity.

Due to the unique advantages of perovskite material which possess the ability to transport electron and hole, as 


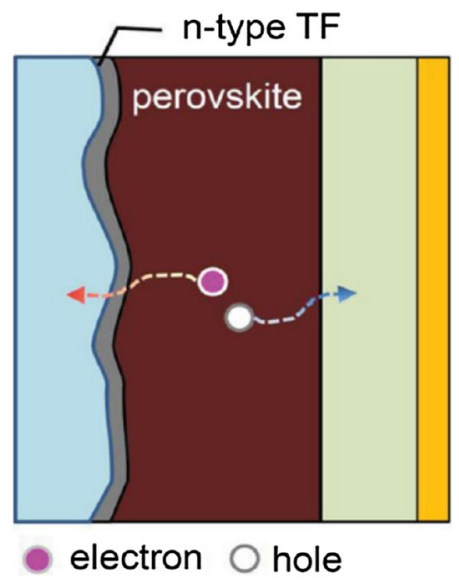

Fig. 2 Schematic diagram of working principle for PSC [42]

showed by previous study which simulated the possibility of forming a PSC without HTM [43]. This cell pattern, however, depends on the work function of the back contact with energy of the valence band ( $\left.E_{\mathrm{v} \_ \text {absorber }}\right)$. This simulation is further supported experimentally by another literature [37]. Although HTM-free PSC is possible, several other researchers proved the importance of having a HTM in PSC is rather important and could affect to a positive increment of several outcomes namely PCE, FF, $V_{\text {oc, }}$ decreases the internal resistance of the cell as well as increases the electron lifetime thus promoting electron collection and indirectly preventing electron-hole recombination.

\section{Material and stability of PSC}

Initially, perovskite material is used as sensitizer in dye sensitized solar cell (DSSC) and it is generally in the form of Organolead Halide. The general formula for perovskite is $\mathrm{AMX}_{3}$, where A is Akyl Ammonia cation (ex: $\mathrm{CH}_{3} \mathrm{NH}_{3}$ ), $\mathrm{M}$ is metal cation (ex: $\mathrm{Pb}^{2+}$ ) and $\mathrm{X}$ is Halide Anion (ex: br, $\mathrm{I}^{-}$or $\mathrm{Cl}^{-}$). According to previous research, formability of perovskite material is based on distance ratio between Akylammonia cation-Halide Anion and metal cation-halide anion (A:X and $\mathrm{M}: \mathrm{X})$ [13]. This ratio is known as tolerance factor (TF) [52] and the formula is as below:

$\mathbf{T F}=\left(R_{A}+R_{B}\right) /\left[\sqrt{2\left(R_{B}+R_{X}\right)}\right]$

An ideal perovskite material possess $\mathrm{TF}=1$, where the molecular structure is perfect cubical. Distorted octahedral is to be expected when $\mathrm{TF}<1$ and this might affect the electronic properties of the material. Thus, the best material to form $\mathrm{PSC}$ is small cation ' $\mathrm{A}$ ' that retain ionic radius within the range of $1.60 \AA-2.50 \AA$ will form Perovskite material, thus, Methylammonia, $\mathrm{CH}_{3} \mathrm{NH}_{3}{ }^{+}(1.80 \AA)$, Ethylammonia,
$\mathrm{CH}_{3} \mathrm{CH}_{2} \mathrm{NH}^{3+}(2.30 \AA)$ and Formamidinia, $\mathrm{NH}_{2} \mathrm{CH}=\mathrm{NH}_{2}{ }^{+}$ (1.90-2.20 $\AA$ ) is found to be the most suitable material [15, 53].

The most common perovskite material currently used is methylammonium lead halide $\left(\mathrm{CH}_{3} \mathrm{NH}_{3} \mathrm{PbX}_{3}, \mathrm{X}=\mathrm{F}, \mathrm{Cl}, \mathrm{Br}\right.$ or I), which have suitable optical and electronic properties [23]. The basic steps to produce this solar active layer are to react $\mathrm{PbI}_{2}$ with $\mathrm{CH}_{3} \mathrm{NH}_{3} \mathrm{I}_{2}$. Keeping in mind that this reaction is reversible, in one direction is the formation of perovskite film itself and if reversed, is the decomposition to $\mathrm{PbI}_{2}$. The formation of water soluble $\mathrm{PbI}_{2}$ during the decomposition of perovskite material is the main obstacle that prevents commercialization of perovskite solar cells. Other than humidity, UV-light, solution (perovskite compositions), oxygen and temperature are among the factors that can cause PSC degradation [47, 54-58]. Degradation of PSC due to humidity is described in the following chemical reaction [45]:

$$
\mathrm{CH}_{3} \mathrm{NH}_{3} \mathrm{PbI}_{3}(\mathrm{~S}) \leftrightarrow \mathrm{CH}_{3} \mathrm{NH}_{3} \mathrm{I}(\mathrm{aq})+\mathrm{PbI}_{2}(\mathrm{~S})
$$

Upon contact with humidity, the hygroscopic methylammonium iodide (MAI) is separated from Perovskite crystal and combines with iodine forming aqueous MAI and solid $\mathrm{PbI}_{2}$. In further reaction with humidity, MAI will subsequently decompose to aqueous methylamine, $\mathrm{CH}_{3} \mathrm{NH}_{3}$ (aq) and hydriodic acid, HI (aq):

$\mathrm{CH}_{3} \mathrm{NH}_{3} \mathrm{I}(\mathrm{aq}) \leftrightarrow \mathrm{CH}_{3} \mathrm{NH}_{2}(\mathrm{aq})+\mathrm{HI}_{2}(\mathrm{aq})$

In contact with oxygen, $\mathrm{HI}$ will degrade and produce $\mathrm{H}_{2} \mathrm{O}$ and $\mathrm{I}_{2}$ as below equation:

$4 \mathrm{HI}(\mathrm{aq})+\mathrm{O}_{2}(\mathrm{~g}) \leftrightarrow 2 \mathrm{I}_{2}(\mathrm{~s})+2 \mathrm{H}_{2} \mathrm{O}$

Should the photochemical reaction with UV took place; the reaction will proceed as below:

$2 \mathrm{HI}(\mathrm{aq}) \leftrightarrow \mathrm{H}_{2}(\mathrm{~g})+\mathrm{I}_{2}(\mathrm{~s})$

In addition of humidity, UV-light, solution (perovskite compositions), oxygen and temperature, other related factors were also discovered to affects the solar cells stability. Previous research has found that storage conditions also have an influence over perovskite solar cells stability [59]. Dry air was found to be the most suitable storage atmosphere (during the drying process of HTM) if Spiro-OMeTAD act as the HTM in the cell. Solar device architecture also eventually affects the cells stability. Jose and co-workers found that scaffold structured electron transport layer (ETL) produces better stability than planar structured layer [60]. These two devices, Planar and Scaffold (Fig. 3), were compared in the same controlled atmosphere.

In another study, different ETMs; Spiro-OMeTAD, NiO, $\mathrm{CuI}, \mathrm{CuSCN}$ and $\mathrm{Cu}_{2} \mathrm{O}$, were compared for the most outstanding result with different thickness setting for ETM, absorber layer as well as HTM [32]. It was understood that humidity can cause degradation of PSC. However, using $\mathrm{Cu}_{2} \mathrm{O}$ as the ETM, it was observed that cell degradation 

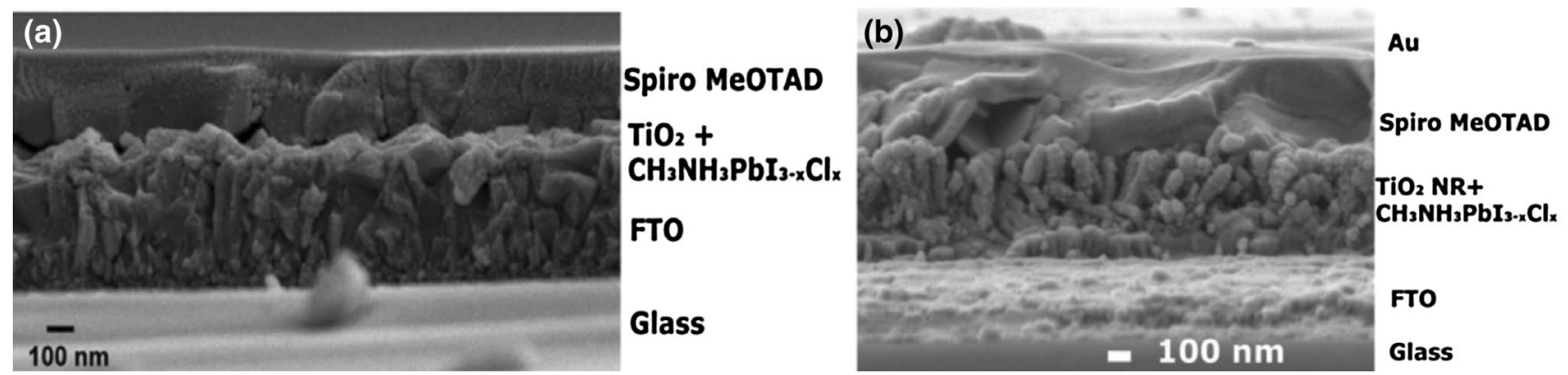

Fig. 3 Planar type cell (a) and Scaffold type cell (b) [40]

caused by moisture can be avoided while maintaining high electron mobility. Cells with $\mathrm{Cu}_{2} \mathrm{O}$ outperform every other ETM. Recent study has also added reduced graphene oxide $(\mathrm{rGO}) /$ mesoporous (mp)- $\mathrm{TiO}_{2}$ nanocomposite based mesostructured perovskite solar cells [61]. The study had demonstrated the improvement in electron transport property and photon conversion efficiency which is contributed by the reduction in resistance at interface.

Recent study has improved the performance and stability issue of PSC by crystal crosslinking with alkylphosphonic (butylphosphonic) acid $\omega$-ammonium chlorides (4-ABPACI) [62]. Through one-step solution processing, spin-coating (which in authors opinion, this is the easiest and most favourable way to fabricate PSC in which, if this method is proved success in producing high-efficiency and high stability PSC would take this technology a wide step forward in commercializing PSC), this team modified the surface of Methylammonium Lead Triiodide in the presence of alkylphosphonic acid $\omega$-ammonium chlorides as the crosslink between neighbouring grains in the perovskite structure. 4-ABPACI act not only to increase the cells efficiency from 8.8 to $16.7 \%$, but also enhancing its stability against moisture. Using XRD spectra before and after moisture test (comparing Pristine and 4-ABPACI deposited on $\mathrm{mp}-\mathrm{TiO}_{2} / \mathrm{FTO}$ ), Pristine cells suffer from severe corrosion compared to 4-ABPACI cells. Other moisture barrier such as carbon cathode or $\mathrm{Al}_{2} \mathrm{O}_{3}$ is also quite suitable; however, it might be not suitable enough for widespread and long term stability, more extensive stabilizer is required.

Encapsulation method has also been proven to be able to influence the stability of PSC. When two encapsulation techniques were compared, it was demonstrated that stability of PSC fabricated with encapsulation adopted from organic light emitting diode (OLED) technology was able to yield improved stability under high humidity environments compared to typical UV curable epoxy resin method [63]. It was stated that the OLED method uses a desiccant material that absorbs water that may penetrate through the epoxy resin sealant.
Wang and co-workers said that in order for thin film solar cell to be fully commercialized, it is important that it complies with IEC 61646 testing standard which refers to environmental stability, which is at current research finding, this is the big thing to be solved [64]. In their paper, they address the stability issue based on the whole cell structure including the perovskite material itself, ETM and HTM layers, buffer layer as well as both of the electrodes. However, they stress more on the importance of the encapsulation layer while maintaining lead-based Perovskite material. Using lead-based perovskite is undeniably attractive due to high PCE as shown by many (as shown in Table 1). Nevertheless, controlling the stability only from the encapsulation will only reduce several percent of ecotoxicity from lead as the demand for lead is still available, which means the processing of lead is still exist. From authors' point of view, the best method to tackle this problem is to find a suitable replacement for lead to be used in PSC.

The above arguments can be supported by previous research [65]. For the first time, their team had reported the life cycle assessment (LCA) on ecotoxicity of PSC. Fabrication is based on two most successive reported articles on fabricating PSC that is Vapour Phase Deposition and Solution Processing. They concluded that the major contributor to negative environmental effect comes from the manufacturing process itself. The electricity required to fabricate the cell is the main arguments for this paper, and this by all means covers vapour and solution deposition. The only difference is the percentage of contribution between these two processing methods. Additionally, the life cycle impact analysis revealed that in both deposition processes, the impact was focused primarily on the human toxicity (cancer effect) and freshwater ecotoxicity, which is due to lead emission $[65,66]$. However, the article suggested that PSC technology does not pose concern in its raw materials extraction, synthesis of the starting materials and manufacture of the PSC as compared to the other solar cell technologies. In another LCA, the research focuses on the difference of $\mathrm{TiO}_{2}$ module and $\mathrm{ZnO}$ module for PSC [67]. The study found that both PSC modules have the shortest energy payback 
time compared to the other solar cell technologies while emphasizing on reducing the high energy demand processes to lower the $\mathrm{CO}_{2}$ emission factor.

\section{Lead-free perovskite solar cell}

Albeit the high-performance of PSCs with relatively high stability [68], the presence of lead has been taken into caution by the many researchers. The usage of such material has caused a relative concern due to obey strict requirement to be environmental friendly which hindered the large-scale implementation of perovskite solar cells. The main concern is circulated upon the possibility of solar modules would somehow crack under environmental hazards such as hail or earthquake, and thus releasing the degraded perovskite products into the environment [69]. Previous study had argued that the $\mathrm{Pb}$ content in PSC could deter market acceptance due to its risk towards human health and ecosystem [70]. To such extent, researchers are in the effort to replace $\mathrm{Pb}$ with other suitable materials to alleviate the toxicity issues in PSCs [71-75]. Suitable materials which have been proposed so far includes tin (Sn), bismuth (Bi), germanium (GE) and copper $(\mathrm{Cu})$ [76]. Table 2 summarizes the main research on lead-free perovskite and their performance.

$\mathrm{Sn}$ has been considered as a suitable substitution for $\mathrm{Pb}$ in perovskite solar cells due to their similarity in chemical properties [48, 49]. The use of Sn-based perovskite has been implemented in transistor with excellent charge motilities [88]. The application of $\mathrm{Sn}$ in perovskite solar cells usually involved the alloying of $\mathrm{Sn} / \mathrm{Pb}$ with the recent study recording a $15 \%$ efficiency in oxygen deficient environment as well as in tandem applications [77, 89-91]. Ogomi et al. was one of the first to vary the composition of $\mathrm{Pb}: \mathrm{Sn}$ ratio and tested the performance of perovskite solar cells [78]. They had proved the possibility of Sn could be a possible option as the absorber material for solar cells, but also showed that pure Sn perovskite solar cells did not produce any photovoltaic performance. It was also demonstrated that Sn would able to intrinsically maintain its $2+$ oxidation state with the presence of $\mathrm{Pb}$ in the absorber layer. Nevertheless, Snaith et al. has fabricated a totally $\mathrm{Pb}$-free perovskite solar cells using $\mathrm{MASnI}_{3}$ as the perovskite light absorber with encapsulation and in nitrogen environment glovebox to prevent the degradation of the Sn-based perovskite absorber [49]. The study also mentioned the stability issues of Sn-based perovskite where a discoloration was observed within seconds after the absorber layer was exposed to the ambient atmosphere due to the intrinsic property of $\mathrm{Sn}^{2+}$ to oxidise rapidly to $\mathrm{Sn}^{4+}$ in the presence of oxygen [69]. However, fabrication of a complete cell was successful while in the nitrogen environment. Despite the stability issues, the study also mentioned the possibility of $\mathrm{Pb}$-free perovskite to be employed in perovskite solar cells with toxicology advantage over the Pb-based perovskite solar cells.

In comparison towards $\mathrm{Pb}$-based perovskite absorber, a research has compared the properties (crystal structure, optical properties and charge transporting properties) of $\mathrm{Pb}$-based and Sn-based of methylammonium (MA) and formamidinium (FA) halide perovskite, respectively [92]. It was demonstrated that the band gaps were ranging from 1.1 to $1.7 \mathrm{eV}$ and showed excellent photoluminescence properties suitable for solar cell applications. Although the oxidation of $\mathrm{Sn}^{2+}$ to $\mathrm{Sn}^{4+}$ was also observed here, improved stability with high electron and hole motilities was recorded which shown potential towards $\mathrm{Pb}$-free absorber layer. When $\mathrm{Pb}$ and $\mathrm{Sn}$ is applied simultaneously $\left(\mathrm{MAPb}_{1-\mathrm{x}} \mathrm{Sn}_{\mathrm{x}} \mathrm{I}_{3}\right)$ in the absorber layer, it was found out that the band gap values do not behave consistently with the increase in substitution rate [79]. At low concentration of $\mathrm{Sn}$, the band gap decreases, then minimum band gap value at $x=0.5$ and 0.75 , and lastly increases to $1.30 \mathrm{~V}$ when

Table 2 Research on lead free perovskite and its performance

\begin{tabular}{llllcc}
\hline References & Device description & $J_{\text {SC }}\left(\mathrm{mA} / \mathrm{cm}^{2}\right)$ & $V_{\text {OC }}(\mathrm{V})$ & FF & PCE $(\%)$ \\
\hline$[77]$ & $\begin{array}{l}\text { Combination of formamidinium tin iodide with methylammonium lead iodide } \\
\text { in inverted PSC }\end{array}$ & 26.86 & 0.795 & 70.6 & 15.08 \\
& Mixed Sn/Pb perovskite in mesoscopic PSC and P3HT as HTM & 20.04 & 0.42 & 0.5 & 4.18 \\
{$[78]$} & Mixed Sn/Pb perovskite with mesoscopic PSC and spiro-MeOTAD as HTM & 20.64 & 0.584 & 60.32 & 7.27 \\
{$[79]$} & Cesium Tin iodide in mesoscopic PSC with SnF metallic control layer & 22.70 & 0.24 & 0.37 & 2.02 \\
{$[80]$} & Impact of anionic Br substitution in cesium tin iodide PSC & 15.06 & 0.289 & 0.38 & 1.67 \\
{$[81]$} & Application of cesium tin perovskite in planar structure & 12.30 & 0.430 & 0.395 & 2.13 \\
{$[82]$} & Formamidinium tin bromide perovskite in inverted structure & 6.82 & 0.467 & 0.540 & 1.72 \\
{$[83]$} & Cesium germanium iodide perovskite in mesoscopic PSC & 5.7 & 0.074 & 0.27 & 0.11 \\
{$[84]$} & Ratio of anionic Cl/Br modification in methylammonium Cupric PSC & 0.216 & 0.256 & 0.32 & 0.017 \\
{$[85]$} & Bismuth-based perovskite in mesoscopic PSC with P3HT as HTM & 1.157 & 0.354 & 0.464 & 0.190 \\
{$[86]$} & Bismuth-based perovskite in mesoscopic PSC with spiro-MeOTAD as HTM & 0.52 & 0.68 & 0.33 & 0.12 \\
{$[87]$} & & &
\end{tabular}


$\mathrm{Pb}$-free perovskite was tested. When the perovskite solar cells were fabricated, lead-free device was performing at $5.44 \%$ efficiency compared to $\mathrm{Pb}-$ based device at $8.31 \%$. Additionally, it was mention that since the absorber layer showed activation towards near-IR region, it can be beneficial in both single junction and in tandem architecture where the band gap is required to be near $1 \mathrm{eV}$ [93]. On the other hand, investigation on mixed halide $\mathrm{Sn}$-based perovskite MASn $\mathrm{I}_{3-\mathrm{x}} \mathrm{Br}_{\mathrm{x}}$ showed an increasing energy band gap values towards higher Br-content (1.30-2.15 eV) [48]. Figure 4a shows the mesoscopic structure of the solar cell device with the colour change in different absorber layers on the right panel. It was stated that the lighter colours of the larger band gaps are attributed by the narrowed light absorption range of the absorber (Fig. 4b). It was reported that the higher Br-content absorber possess higher open circuit voltage $\left(V_{\mathrm{oc}}\right)$ and a lower short-circuit photocurrent density $\left(J_{\mathrm{sc}}\right)$. Most importantly, the spontaneous decomposition of the absorber layer were reported with
$36 \%$ reduction in performance while stored in nitrogen environment and encapsulated.

In addition to MA and FA halide perovskite absorbers, Cs halide perovskite have also been investigated with $\mathrm{Sn}$ to study their compatibility [80, 81]. With lower energy bandgap of $1.3 \mathrm{eV}$, the $\mathrm{CsSnI}_{3}$ perovskite absorber could harvest light at near-IR region and possess short-circuit photocurrent density of $34.3 \mathrm{mAcm}^{-2}$. It was mentioned that the metallic nature of the $\mathrm{CsSnI}_{3}$ was alleviated by doping with $20 \%$ $\mathrm{SnF}_{2}$ by reducing the background carrier density [80].

Organolead halide perovskite have also been investigated in inverted planar structure solar cells, with the usage of fullerene and its derivatives for the electron transporting layer, instead of inorganic metal oxide [94-96]. The incorporation of Sn has been reported by a study employing a structure of $\mathrm{ITO} / \mathrm{CuI} / \mathrm{CsSnI}_{3} / \mathrm{C}_{60} / \mathrm{BCP} /$ Al [82]. The study also demonstrated the improvement in stability and performance using excess amount $\mathrm{SnI}_{2}$ during the synthesis of $\mathrm{CsSnI}_{3}$. The excess amount of
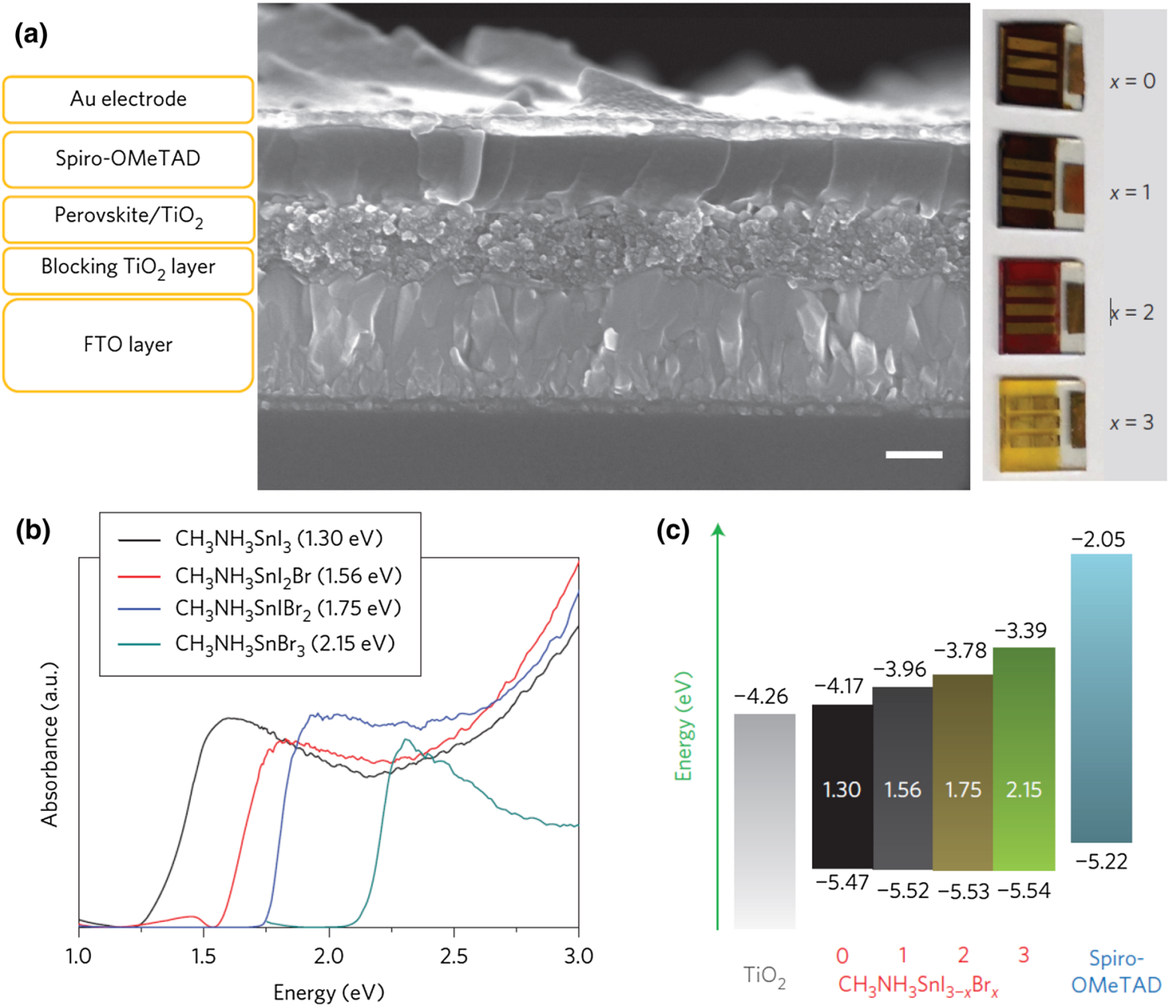

Fig. 4 a Perovskite solar cell device architecture with different absorber layer colour on the right panel. b Absorption spectra of the $\mathrm{CH}_{3} \mathrm{NH}_{3} \mathrm{SnI}_{3-\mathrm{x}} \mathrm{Br}_{\mathrm{x}}(x=0,1,2,3)$ perovskites. c Schematic energy-level diagram of $\mathrm{CH}_{3} \mathrm{NH}_{3} \mathrm{SnI}_{3-\mathrm{x}} \mathrm{Br}_{\mathrm{x}}$ with $\mathrm{TiO}_{2}$ and spiro-OMeTAD HTM 
$\mathrm{SnI}_{2}$ is postulated to be able to minimize the Sn vacancy defects of the tin-halide perovskite which contributes to the metallic nature of Sn. Low temperature processing was utilized in the fabrication of solar cell devices with inverted planar structure of ITO/PEDOT:PSS/FASnI ${ }_{2} \mathrm{Br} /$ $\mathrm{C}_{60} / \mathrm{Ca} / \mathrm{Al}$ [83]. With a combination of $\mathrm{FASnI}_{2} \mathrm{Br}$ (bandgap of $1.68 \mathrm{eV}$ ) and low temperature annealing $\left(75^{\circ} \mathrm{C}\right)$, a power conversion efficiency of $1.72 \%$ was achieved with maintaining more than $60 \%$ performance efficiency after $30 \mathrm{~h}$ in nitrogen environment.

Ge-based perovskite have shown some potential as the absorber layer for photovoltaic solar cells based on density functional theory [97]. The study had prepared a series of Ge-based perovskite using Cs, MA, FA, acetamidinium, guanidinium, trimethylammonium, and isopropylammonium, to evaluate their potential as a perovskite absorber layer. It was demonstrated that these materials possess slightly higher bandgaps that the $\mathrm{Pb}$ counterparts, however, the problem of material stability is also present. It was demonstrated that the Ge-based perovskite performance in $V_{\mathrm{oc}}$ was poor and the recorded efficiency was only $0.2 \%$ [84].

$\mathrm{Cu}$-based perovskite have also received attention due to its stability in air $[98,99]$. Compared to the 3D perovskites, $\mathrm{Cu}$-based perovskite are $2 \mathrm{D}$ with multi quantum-well electronic structure, presenting particular electronic, magnetic and dielectric properties [85, 88, 98, 100]. A study had fabricated $\mathrm{Cu}$-based solar cells using $\left(\mathrm{CH}_{3} \mathrm{CH}_{2} \mathrm{CH}_{2} \mathrm{CH}_{2} \mathrm{NH}_{3}\right)_{2} \mathrm{CuBr}_{4}$ and $\left(\mathrm{F}-\mathrm{C}_{8} \mathrm{H}_{8} \mathrm{NH}_{3}\right)_{2} \mathrm{CuBr}_{4}$, with power conversion efficiency of 0.63 and $0.51 \%$, respectively [98]. A study was focusing on the $\mathrm{Br} / \mathrm{Cl}$ ratio to tune the light adsorption properties of $\mathrm{Cu}$-based perovskite [99]. The study had postulated that the poor power conversion efficiency obtained was contributed by low absorption coefficient and heavy mass for the holes.

Bi-based perovskite, $\mathrm{A}_{3} \mathrm{Bi}_{2} \mathrm{X}_{9}$ has attracted considerable attention due to its interesting properties [72, 86, 87, 101-104]. Bi-based perovskite have excellent stability towards moisture and less toxic compared to $\mathrm{Pb}$-based perovskite. The 0D perovskite is formed due to bioctahedral $\left(\mathrm{Bi}_{2} \mathrm{I}_{9}\right)^{3-}$ clusters and the surrounding cations, as shown in Fig. 5. Previous study has demonstrated the stability of $\mathrm{MA}_{3} \mathrm{Bi}_{2} \mathrm{I}_{9}$ in ambient environment for more than 40 days [72]. Nevertheless, the performance efficiency was sub-par with conventional structure $(0.19 \%)$ and inverted planar structure $(0.1 \%)[86,87]$. On the other hand, $\mathrm{Cs}_{3} \mathrm{Bi}_{2} \mathrm{I}_{9}$ perovskite had performed slightly better at $1.09 \%$ efficiency [72]. The performance of Bi-based perovskite is not as high as its $\mathrm{Pb}$ counterparts. Nevertheless, its potential as a less toxic alternative with high stability is expected to present some improvement in performance efficiency in the near future.

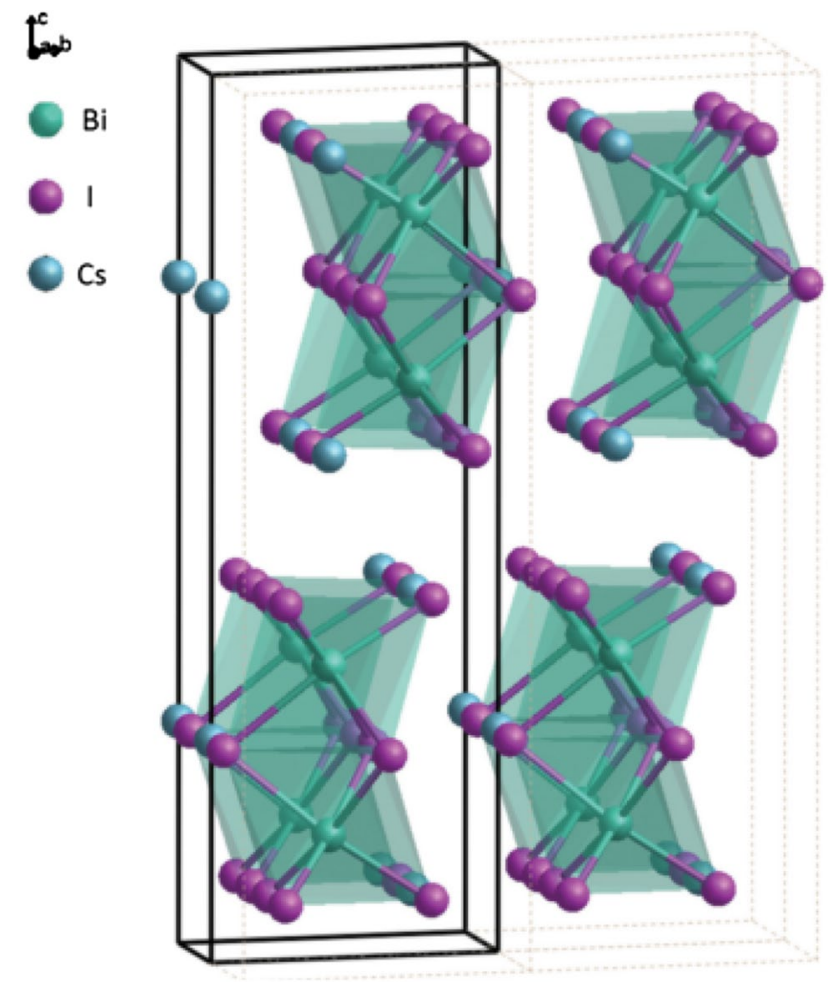

Fig. 5 Schematic diagram of Bi-based perovskite $\left(\mathrm{Cs}_{3} \mathrm{Bi}_{2} \mathrm{I}_{9}\right)$

\section{Conclusion and future prospect}

In conclusion, this review concerns the material stability of $\mathrm{Pb}$-based perovskite and the alternative replacement for $\mathrm{Pb}$-based perovskite in photovoltaic solar cells. In the effort to manage the material instability of Pb-based perovskite, researcher often opt for improving fabrication technique or simply replace the $\mathrm{Pb}$-based perovskite with alternative material. Although several materials have been proposed, most of them either still possess some extend of stability or inherently produce low performance efficiency. Developing suitable encapsulation technique may be relevant towards enhancing perovskite resistivity towards moisture. Material selection at the ETM and HTM may also contribute to a higher performance efficiency. Although the performance efficiency of $\mathrm{Pb}$-alternative perovskite is still relatively low, the study is still at its infancy. Progress is expected at this study due to the less toxic with high stability perovskite available. Research output are expected towards this aim which may transform perovskite solar cells toward a truly green, highly stable and low-cost photovoltaic solar cells.

Acknowledgements The authors acknowledge the financial support by the Universiti Kebangsaan Malaysia (UKM) under the Research University Grant (GUP-2015-037) and Dana Impak Perdana (DIP2016-025). The authors would also like to acknowledge technical and management support from Centre for Research and Instrumentation

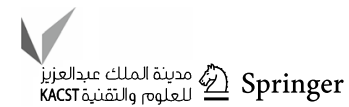


(CRIM), UKM. The first author also would like to acknowledge UKM for PhD scholarship under the Skim Zamalah Yayasan Canselor 2016.

Open Access This article is distributed under the terms of the Creative Commons Attribution 4.0 International License (http://creativeco mmons.org/licenses/by/4.0/), which permits unrestricted use, distribution, and reproduction in any medium, provided you give appropriate credit to the original author(s) and the source, provide a link to the Creative Commons license, and indicate if changes were made.

\section{References}

1. El Chaar, L., Lamont, L.A., El Zein, N.: Review of photovoltaic technologies. Renew. Sustain. Energy Rev. 15, 2165-2175 (2011). https://doi.org/10.1016/j.rser.2011.01.004

2. Smith, D.D., Reich, G., Baldrias, M., Reich, M., Boitnott, N., Bunea, G.: Silicon solar cells with total area efficiency above 25\%. Conf. Rec. IEEE Photovolt. Spec. Conf. 2016, 3351-3355 (2016). https://doi.org/10.1109/pvsc.2016.7750287

3. Best Research-Cell Efficiencies. https://www.nrel.gov/pv/assets/ images/efficiency-chart.png. Accessed 2 March 2017

4. Sepeai S., Zaidi S.H., Cheow S.L., Sulaiman M.Y., Sopian K., Azhari A.W., Ludin N.A., Khairunaz M.: Evaluation of surface photovoltage (SPV) in Al-back surface fields bifacial solar cell. In: Latest Trends Renew. Energy Environ. Informatics, pp. 81-83 (2013)

5. Barrioz, V., Monir, S., Kartopu, G., Lamb, D.A., Brooks, W., Siderfin, P., Jones, S., Clayton, A.J., Irvine, S.J.C.: MOCVD for solar cells, a transition towards a chamberless inline process. J. Cryst. Growth 414, 223-231 (2015). https://doi.org/10.1016/j. jcrysgro.2014.11.014

6. Zhou, Y., Wang, L., Chen, S., Qin, S., Liu, X., Chen, J., Xue, D.-J., Luo, M., Cao, Y., Cheng, Y., Sargent, E.H., Tang, J.: Thinfilm $\mathrm{Sb}_{2} \mathrm{Se}_{3}$ photovoltaics with oriented one-dimensional ribbons and benign grain boundaries. Nat. Photonics 9, 409-415 (2015). https://doi.org/10.1038/nphoton.2015.78

7. Clayton, A.J., Irvine, S.J., Jones, E.W., Kartopu, G., Barrioz, V., Brooks, W.S.: MOCVD of $\mathrm{Cd}_{1-\mathrm{x}} \mathrm{Zn}_{\mathrm{x}} \mathrm{S} / \mathrm{CdTe}$ PV cells using an ultra-thin absorber layer. Sol. Energy Mater. Sol. Cells 101, 68-72 (2012). https://doi.org/10.1016/j.solmat.2012.02.018

8. Harikisun, R., Desilvestro, H.: Long-term stability of dye solar cells. Sol. Energy 85, 1179-1188 (2011). https://doi. org/10.1016/j.solener.2010.10.016

9. Widodo, S., Wiranto, G., Hidayat, M.N.: Fabrication of dye sensitized solar cells with spray coated carbon nano tube (CNT) based counter electrodes. Energy Procedia. 68, 37-44 (2015). https://doi.org/10.1016/j.egypro.2015.03.230

10. Li, X., Bi, D., Yi, C., Decoppet, J.-D., Luo, J., Zakeeruddin, S.M., Hagfeldt, A., Gratzel, M.: A vacuum flash-assisted solution process for high-efficiency large-area perovskite solar cells. Science 353, 58-62 (2016). https://doi.org/10.1126/science.aaf80 60

11. Kouhnavard, M., Ludin, N.A., Ghaffari, B.V., Ikeda, S., Sopian, K., Miyake, M.: Hydrophilic carbon/ $/ \mathrm{TiO}_{2}$ colloid composite: a potential counter electrode for dye-sensitized solar cells. J. Appl. Electrochem. 46, 259-266 (2016). https://doi.org/10.1007/s1080 0-015-0910-4

12. Kouhnavard, M., Ahmad Ludin, N., Vazifehkhah Ghaffari, B., Sopian, K., Abdul Karim, N., Miyake, M.: An efficient metalfree hydrophilic carbon as a counter electrode for dye-sensitized solar cells. Int. J. Photoenergy 2016, 1-7 (2016). https://doi. org/10.1155/2016/5186762
13. Kouhnavard, M., Ikeda, S., Ludin, N.A.A., Ahmad Khairudin, N.B.B., Ghaffari, B.V.V., Mat-Teridi, M.A., Ibrahim, M.A.A., Sepeai, S., Sopian, K.: A review of semiconductor materials as sensitizers for quantum dot-sensitized solar cells. Renew. Sustain. Energy Rev. 37, 397-407 (2014). https://doi.org/10.1016/j. rser.2014.05.023

14. Park, N.: Perovskite solar cells: an emerging photovoltaic technology. Mater. Today 18, 65-72 (2014). https://doi.org/10.1016/j. mattod.2014.07.007

15. Boix, P.P., Nonomura, K., Mathews, N., Mhaisalkar, S.G.: Current progress and future perspectives for organic/inorganic perovskite solar cells. Mater. Today 17, 16-23 (2014). https://doi. org/10.1016/j.mattod.2013.12.002

16. Yang, Z., Zhang, W.-H.: Organolead halide perovskite: a rising player in high-efficiency solar cells. Chin. J. Catal. 35, 983-988 (2014). https://doi.org/10.1016/S1872-2067(14)60162-5

17. Mesquita, I., Andrade, L., Mendes, A.: Perovskite solar cells: materials, configurations and stability. Renew. Sustain. Energy Rev. 82, 2471-2489 (2018). https://doi.org/10.1016/j. rser.2017.09.011

18. Liu, T., Chen, K., Hu, Q., Zhu, R., Gong, Q.: Inverted perovskite solar cells: progresses and perspectives. Adv. Energy Mater. (2016). https://doi.org/10.1002/aenm.201600457

19. Correa Baena, J.P., Steier, L., Tress, W., Saliba, M., Neutzner, S., Matsui, T., Giordano, F., Jacobsson, T.J., Srimath Kandada, A.R., Zakeeruddin, S.M., Petrozza, A., Abate, A., Nazeeruddin, M.K., Grätzel, M., Hagfeldt, A.: Highly efficient planar perovskite solar cells through band alignment engineering. Energy Environ. Sci. 8, 2928-2934 (2015). https://doi.org/10.1039/C5EE02608C

20. Anaraki, E.H., Kermanpur, A., Steier, L., Domanski, K., Matsui, T., Tress, W., Saliba, M., Abate, A., Grätzel, M., Hagfeldt, A., Correa-Baena, J.-P.: Highly efficient and stable planar perovskite solar cells by solution-processed tin oxide. Energy Environ. Sci. 9, 3128-3134 (2016). https://doi.org/10.1039/C6EE02390H

21. Di Giacomo, F., Zardetto, V., D’Epifanio, A., Pescetelli, S., Matteocci, F., Razza, S., Di Carlo, A., Licoccia, S., Kessels, W.M.M., Creatore, M., Brown, T.M.: Flexible perovskite photovoltaic modules and solar cells based on atomic layer deposited compact layers and UV-irradiated $\mathrm{TiO}_{2}$ Scaffolds on plastic substrates. Adv. Energy Mater. 5 (2015). https://doi.org/10.1002/ aenm. 201401808

22. Parisi, M.L., Maranghi, S., Basosi, R.: The evolution of the dye sensitized solar cells from Grätzel prototype to up-scaled solar applications: a life cycle assessment approach. Renew. Sustain. Energy Rev. 39, 124-138 (2014). https://doi.org/10.1016/j. rser.2014.07.079

23. Grätzel, M.: The light and shade of perovskite solar cells. Nat. Mater. 13, 838-842 (2014). https://doi.org/10.1038/nmat4065

24. Kojima, A., Teshima, K., Shirai, Y., Miyasaka, T.: Organometal halide perovskites as visible-light sensitizers for photovoltaic cells. J. Am. Chem. Soc. 131, 6050-6051 (2009). https://doi. org/10.1021/ja809598r

25. Saliba, M., Matsui, T., Domanski, K., Seo, J.-Y., Ummadisingu, A., Zakeeruddin, S.M., Correa-Baena, J.-P., Tress, W.R., Abate, A., Hagfeldt, A., Gratzel, M.: Incorporation of rubidium cations into perovskite solar cells improves photovoltaic performance. Science 354, 206-209 (2016). https://doi.org/10.1126/scien ce.aah5557

26. Liu, J., Lin, J., Xue, Q., Ye, Q., He, X., Ouyang, L., Zhuang, D., Liao, C., Yip, H.-L., Mei, J., Lau, W.-M.: Growth and evolution of solution-processed $\mathrm{CH}_{3} \mathrm{NH}_{3} \mathrm{PbI}_{3-\mathrm{x}} \mathrm{Cl}_{\mathrm{x}}$ layer for highly efficient planar-heterojunction perovskite solar cells. J. Power Sources 301, 242-250 (2016). https://doi.org/10.1016/j.jpows our.2015.10.023

27. Ripolles, T.S., Nishinaka, K., Ogomi, Y., Miyata, Y., Hayase, S.: Efficiency enhancement by changing perovskite crystal phase 
and adding a charge extraction interlayer in organic amine freeperovskite solar cells based on cesium. Sol. Energy Mater. Sol. Cells 144, 532-536 (2016). https://doi.org/10.1016/j.solma t.2015.09.041

28. Yang, W.S., Noh, J.H., Jeon, N.J., Kim, Y.C., Ryu, S., Seo, J., Il Seok, S.: High-performance photovoltaic perovskite layers fabricated through intramolecular exchange, Science (80-.). 348 (2015) science.aaa9272-. https://doi.org/10.1126/science.aaa92 72

29. Chen, L.-C., Chen, C.-C., Chen, J.-C., Wu, C.-G.: Annealing effects on high-performance $\mathrm{CH}_{3} \mathrm{NH}_{3} \mathrm{PbI}_{3}$ perovskite solar cells prepared by solution-process. Sol. Energy 122, 1047-1051 (2015). https://doi.org/10.1016/j.solener.2015.10.019

30. Casaluci, S., Cinà, L., Pockett, A., Kubiak, P.S., Niemann, R.G., Reale, A., Di Carlo, A., Cameron, P.J.: A simple approach for the fabrication of perovskite solar cells in air. J. Power Sources 297, 504-510 (2015). https://doi.org/10.1016/j.jpowsour.2015.08.010

31. Sheikh, A.D., Bera, A., Haque, A., Rakhi, R.B., Del, S., Alshareef, H.N., Wu, T.: Atmospheric effects on the photovoltaic performance of hybrid perovskite solar cells. Sol. Energy Mater. Sol. Cells 137, 6-14 (2015). https://doi.org/10.1016/j.solma t.2015.01.023

32. Hossain, M.I., Alharbi, F.H., Tabet, N.: Copper oxide as inorganic hole transport material for lead halide perovskite based solar cells. Sol. Energy 120, 370-380 (2015). https://doi. org/10.1016/j.solener.2015.07.040

33. Tavakoli, M.M., Gu, L., Gao, Y., Reckmeier, C., He, J., Rogach, A.L., Yao, Y., Fan, Z.: Fabrication of efficient planar perovskite solar cells using a one-step chemical vapor deposition method. Sci. Rep. 5, 14083 (2015). https://doi.org/10.1038/srep14083

34. Zhang, Z., Wei, D., Xie, B., Yue, X., Li, M., Song, D., Li, Y.: High reproducibility of perovskite solar cells via a complete spincoating sequential solution deposition process. Sol. Energy 122, 97-103 (2015). https://doi.org/10.1016/j.solener.2015.08.028

35. Huang, C., Fu, N., Liu, F., Jiang, L., Hao, X., Huang, H.: Highly efficient perovskite solar cells with precursor compositiondependent morphology. Sol. Energy Mater. Sol. Cells 145, 231237 (2016). https://doi.org/10.1016/j.solmat.2015.10.032

36. Xiao, Y., Han, G., Chang, Y., Zhang, Y., Li, Y., Li, M.: Investigation of perovskite-sensitized nanoporous titanium dioxide photoanodes with different thicknesses in perovskite solar cells. J. Power Sources 286, 118-123 (2015). https://doi.org/10.1016/j. jpowsour.2015.03.152

37. Bhatt, P., Pandey, K., Yadav, P., Tripathi, B., Chandra Kanth, P., Pandey, M.K., Kumar, M.: Investigating the charge carrier transport within the hole-transport material free perovskite solar cell processed in ambient air. Sol. Energy Mater. Sol. Cells 140, 320-327 (2015). https://doi.org/10.1016/j.solmat.2015.04.028

38. Sfyri, G., Kumar, C.V., Raptis, D., Dracopoulos, V., Lianos, P.: Study of perovskite solar cells synthesized under ambient conditions and of the performance of small cell modules. Sol. Energy Mater. Sol. Cells 134, 60-63 (2015). https://doi.org/10.1016/j. solmat.2014.11.034

39. Jeon, N.J., Noh, J.H., Kim, Y.C., Yang, W.S., Ryu, S., Il Seok, S.: Solvent engineering for high-performance inorganic-organic hybrid perovskite solar cells. Nat. Mater. 13, 1-7 (2014). https:// doi.org/10.1038/nmat4014

40. Im, J.-H., Kim, H.-S., Park, N.-G.: Morphology-photovoltaic property correlation in perovskite solar cells: one-step versus two-step deposition of $\mathrm{CH}_{3} \mathrm{NH}_{3} \mathrm{PbI}_{3}$. APL Mater. 2, 81510 (2014). https://doi.org/10.1063/1.4891275

41. Ding, Y., Yao, X., Zhang, X., Wei, C., Zhao, Y.: Surfactant enhanced surface coverage of $\mathrm{CH}_{3} \mathrm{NH}_{3} \mathrm{PbI}_{3-\mathrm{x}} \mathrm{Cl}_{\mathrm{x}}$ perovskite for highly efficient mesoscopic solar cells. J. Power Sources. (2014). https://doi.org/10.1016/j.jpowsour.2014.08.095. (Ahead of Print)
42. Di Giacomo, F., Razza, S., Matteocci, F., D’Epifanio, A., Licoccia, S., Brown, T.M., Di Carlo, A.: High efficiency $\mathrm{CH} 3 \mathrm{NH} 3 \mathrm{PbI}(3-\mathrm{x}) \mathrm{Clx}$ perovskite solar cells with poly(3-hexylthiophene) hole transport layer. J. Power Sources 251, 152-156 (2014). https://doi.org/10.1016/j.jpowsour.2013.11.053

43. Minemoto, T., Murata, M.: Theoretical analysis on effect of band offsets in perovskite solar cells. Sol. Energy Mater. Sol. Cells 133, 8-14 (2014). https://doi.org/10.1016/j.solmat.2014.10.036

44. Jung, H.S., Park, N.-G.G.: Perovskite solar cells: from materials to devices. Small 11, 10-25 (2015). https://doi.org/10.1002/ smll.201402767

45. Chen, Q., De Marco, N., Yang, Y., Bin Song, T., Chen, C.C., Zhao, H., Hong, Z., Zhou, H., Yang, Y.: Under the spotlight: the organic-inorganic hybrid halide perovskite for optoelectronic applications. Nano Today. 10, 355-396 (2015). https:// doi.org/10.1016/j.nantod.2015.04.009

46. Petrović, M., Chellappan, V., Ramakrishna, S.: Perovskites: solar cells and engineering applications-materials and device developments. Sol. Energy 122, 678-699 (2015). https://doi. org/10.1016/j.solener.2015.09.041

47. Shahbazi, M., Wang, H.: Progress in research on the stability of organometal perovskite solar cells. Sol. Energy 123, 74-87 (2016). https://doi.org/10.1016/j.solener.2015.11.008

48. Hao, F., Stoumpos, C.C., Cao, D.H., Chang, R.P.H., Kanatzidis, M.G.: Lead-free solid-state organic-inorganic halide perovskite solar cells. Nat. Photonics 8, 489-494 (2014). https://doi. org/10.1038/nphoton.2014.82

49. Noel, N.K., Stranks, S.D., Abate, A., Wehrenfennig, C., Guarnera, S., Haghighirad, A.-A., Sadhanala, A., Eperon, G.E., Pathak, S.K., Johnston, M.B., Petrozza, A., Herz, L.M., Snaith, H.J.: Lead-free organic-inorganic tin halide perovskites for photovoltaic applications. Energy Environ. Sci. 7, 3061 (2014). https ://doi.org/10.1039/C4EE01076K

50. Stranks, S.D., Snaith, H.J.: Metal-halide perovskites for photovoltaic and light-emitting devices. Nat. Nanotechnol. 10, 391-402 (2015). https://doi.org/10.1038/nnano.2015.90

51. Koh, T.M., Krishnamoorthy, T., Yantara, N., Shi, C., Leong, W.L., Boix, P.P., Grimsdale, A.C., Mhaisalkar, S.G., Mathews, N.: Formamidinium tin-based perovskite with low $\mathrm{E} g$ for photovoltaic applications. J. Mater. Chem. A. 3, 14996-15000 (2015). https://doi.org/10.1039/C5TA00190K

52. Goldschmidt, V.M.: Die Gesetze der Krystallochemie. Naturwissenschaften 14, 477-485 (1926). https://doi.org/10.1007/BF015 07527

53. Green, M.A., Ho-Baillie, A., Snaith, H.J.: The emergence of perovskite solar cells. Nat Phot 8, 506-514 (2014). https://doi. org/10.1038/nphoton.2014.134

54. Lee, S.-W., Kim, S., Bae, S., Cho, K., Chung, T., Mundt, L.E., Lee, S., Park, S., Park, H., Schubert, M.C., Glunz, S.W., Ko, Y., Jun, Y., Kang, Y., Lee, H.-S., Kim, D.: UV degradation and recovery of perovskite solar cells. Sci. Rep. 6, 38150 (2016). https://doi.org/10.1038/srep38150

55. Dao, Q.-D., Tsuji, R., Fujii, A., Ozaki, M.: Study on degradation mechanism of perovskite solar cell and their recovering effects by introducing $\mathrm{CH}_{3} \mathrm{NH}_{3} \mathrm{I}$ layers. Org. Electron. 43, 229-234 (2017). https://doi.org/10.1016/j.orgel.2017.01.038

56. Berhe, T.A., Su, W.-N., Chen, C.-H., Pan, C.-J., Cheng, J.-H., Chen, H.-M., Tsai, M.-C., Chen, L.-Y., Dubale, A.A., Hwang, B.-J.: Organometal halide perovskite solar cells: degradation and stability. Energy Environ. Sci. 9, 323-356 (2016). https://doi. org/10.1039/C5EE02733K

57. Niu, G., Guo, X., Wang, L.: Review of recent progress in chemical stability of perovskite solar cells. J. Mater. Chem. A. 3, 89708980 (2015). https://doi.org/10.1039/C4TA04994B

58. Leijtens, T., Eperon, G.E., Pathak, S., Abate, A., Lee, M.M., Snaith, H.J.: Overcoming ultraviolet light instability of sensitized

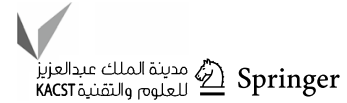


$\mathrm{TiO}_{2}$ with meso-superstructured organometal tri-halide perovskite solar cells. Nat Commun (2013). https://doi.org/10.1038/ ncomms 3885

59. Sheikh, A.D., Bera, A., Haque, M.A., Rakhi, R.B., Del Gobbo, S., Alshareef, H.N., Wu, T.: Atmospheric effects on the photovoltaic performance of hybrid perovskite solar cells. Sol. Energy Mater. Sol. Cells 137, 6-14 (2015). https://doi.org/10.1016/j. solmat.2015.01.023

60. Fakharuddin, A., Di Giacomo, F., Ahmed, I., Wali, Q., Brown, T.M., Jose, R.: Role of morphology and crystallinity of nanorod and planar electron transport layers on the performance and long term durability of perovskite solar cells. J. Power Sources 283, 61-67 (2015). https://doi.org/10.1016/j. jpowsour.2015.02.084

61. Han, G.S., Song, Y.H., Jin, Y.U., Lee, J.W., Park, N.G., Kang, B.K., Lee, J.K., Cho, I.S., Yoon, D.H., Jung, H.S.: Reduced graphene oxide/mesoporous $\mathrm{TiO}_{2}$ nanocomposite based perovskite solar cells. ACS Appl. Mater. Interfaces. 7, 23521-23526 (2015). https://doi.org/10.1021/acsami.5b06171

62. Li, X., Ibrahim Dar, M., Yi, C., Luo, J., Tschumi, M., Zakeeruddin, S.M., Nazeeruddin, M.K., Han, H., Grätzel, M.: Improved performance and stability of perovskite solar cells by crystal crosslinking with alkylphosphonic acid $\omega$-ammonium chlorides. Nat. Chem. 7, 703-711 (2015). https://doi.org/10.1038/nchem .2324

63. Han, Y., Meyer, S., Dkhissi, Y., Weber, K., Pringle, J.M., Bach, U., Spiccia, L., Cheng, Y.-B.: Degradation observations of encapsulated planar $\mathrm{CH}_{3} \mathrm{NH}_{3} \mathrm{PbI}_{3}$ perovskite solar cells at high temperatures and humidity. J. Mater. Chem. A. 3, 8139-8147 (2015). https://doi.org/10.1039/C5TA00358J

64. Wang, D., Wright, M., Elumalai, N.K., Uddin, A.: Stability of perovskite solar cells. Sol. Energy Mater. Sol. Cells 147, 255275 (2016). https://doi.org/10.1016/j.solmat.2015.12.025

65. Espinosa, N., Serrano-Luján, L., Urbina, A., Krebs, F.C.: Solution and vapour deposited lead perovskite solar cells: ecotoxicity from a life cycle assessment perspective. Sol. Energy Mater. Sol. Cells 137, 303-310 (2015). https://doi.org/10.1016/j.solma t.2015.02.013

66. Hauck, M., Ligthart, T., Schaap, M., Boukris, E., Brouwer, D.: Environmental benefits of reduced electricity use exceed impacts from lead use for perovskite based tandem solar cell. Renew. Energy. 111, 906-913 (2017). https://doi.org/10.1016/j.renen e.2017.04.044

67. Gong, J., Darling, S.B., You, F.: Perovskite photovoltaics: lifecycle assessment of energy and environmental impacts. Energy Environ. Sci. 8, 1953-1968 (2015). https://doi.org/10.1039/ C5EE00615E

68. Chen, W., Wu, Y., Yue, Y., Liu, J., Zhang, W., Yang, X., Chen, H., Bi, E., Ashraful, I., Grätzel, M., Han, L.: Efficient and stable large-area perovskite solar cells with inorganic charge extraction layers. Science 350, 944-948 (2015). https://doi.org/10.1126/ science.aad1015

69. Babayigit, A., Ethirajan, A., Muller, M., Conings, B.: Toxicity of organometal halide perovskite solar cells. Nat. Mater. 15, 247-251 (2016). https://doi.org/10.1038/nmat4572

70. Lyu, M., Yun, J.H., Chen, P., Hao, M., Wang, L.: Addressing toxicity of lead: progress and applications of low-toxic metal halide perovskites and their derivatives. Adv Energy Mater (2017). https ://doi.org/10.1002/aenm.201602512

71. Jacobsson, T.J., Pazoki, M., Hagfeldt, A., Edvinsson, T.: Goldschmidt's rules and strontium replacement in lead halogen perovskite solar cells: theory and preliminary experiments on $\mathrm{CH} 3$ NH 3 SrI 3. J. Phys. Chem. C 119, 25673-25683 (2015). https:// doi.org/10.1021/acs.jpcc.5b06436

72. Park, B.W., Philippe, B., Zhang, X., Rensmo, H., Boschloo, G., Johansson, E.M.J.: Bismuth based hybrid perovskites $\mathrm{A}_{3} \mathrm{Bi}_{2} \mathrm{I}_{9}$
(A: methylammonium or cesium) for solar cell application. Adv. Mater. 27, 6806-6813 (2015). https://doi.org/10.1002/ adma.201501978

73. Sun, Y.-Y., Shi, J., Lian, J., Gao, W., Agiorgousis, M.L., Zhang, P., Zhang, S.: Discovering lead-free perovskite solar materials with a split-anion approach. Nanoscale 8, 6284-6289 (2016). https://doi.org/10.1039/C5NR04310G

74. Boix, P.P., Agarwala, S., Koh, T.M., Mathews, N., Mhaisalkar, S.G.: Perovskite solar cells: beyond methylammonium lead iodide. J. Phys. Chem. Lett. 6, 898-907 (2015). https://doi. org/10.1021/jz502547f

75. Giustino, F., Snaith, H.J.: Toward lead-free perovskite solar cells. ACS Energy Lett. 1, 1233-1240 (2016). https://doi. org/10.1021/acsenergylett.6b00499

76. Zhang, M., Lyu, M., Chen, P., Hao, M., Yun, J.-H., Wang, L.: Recent advances in low-toxic lead-free metal halide perovskite materials for solar cell application. Asia-Pacific J. Chem. Eng. 11, 392-398 (2016). https://doi.org/10.1002/apj.1998

77. Liao, W., Zhao, D., Yu, Y., Shrestha, N., Ghimire, K., Grice, C.R., Wang, C., Xiao, Y., Cimaroli, A.J., Ellingson, R.J., Podraza, N.J., Zhu, K., Xiong, R.-G., Yan, Y.: Fabrication of efficient low-bandgap perovskite solar cells by combining formamidinium tin iodide with methylammonium lead iodide. J. Am. Chem. Soc. 138, 12360-12363 (2016). https://doi. org/10.1021/jacs.6b08337

78. Ogomi, Y., Morita, A., Tsukamoto, S., Saitho, T., Fujikawa, N., Shen, Q., Toyoda, T., Yoshino, K., Pandey, S.S., Ma, T., Hayase, S.: CH3NH3SnxPb1-xI3 perovskite solar cells covering up to $1060 \mathrm{~nm}$. J. Phys. Chem. Lett. 5, 1004-1011 (2014). https://doi.org/10.1021/jz5002117

79. Hao, F., Stoumpos, C.C., Chang, R.P.H., Kanatzidis, M.G.: Anomalous band gap behavior in mixed $\mathrm{Sn}$ and $\mathrm{Pb}$ perovskites enables broadening of absorption spectrum in solar cells. J. Am. Chem. Soc. 136, 8094-8099 (2014). https://doi. org/10.1021/ja5033259

80. Kumar, M.H., Dharani, S., Leong, W.L., Boix, P.P., Prabhakar, R.R., Baikie, T., Shi, C., Ding, H., Ramesh, R., Asta, M., Graetzel, M., Mhaisalkar, S.G., Mathews, N.: Lead-free halide perovskite solar cells with high photocurrents realized through vacancy modulation. Adv. Mater. 26, 7122-7127 (2014). https ://doi.org/10.1002/adma.201401991

81. Sabba, D., Mulmudi, H.K., Prabhakar, R.R., Krishnamoorthy, T., Baikie, T., Boix, P.P., Mhaisalkar, S., Mathews, N.: Impact of anionic Br- substitution on open circuit voltage in lead free perovskite $\left(\mathrm{CsSnI}_{3-\mathrm{x}} \mathrm{Br}_{\mathrm{x}}\right)$ solar cells. J. Phys. Chem. C 119, 1763-1767 (2015). https://doi.org/10.1021/jp5126624

82. Marshall, K.P., Walton, R.I., Hatton, R.A.: Tin perovskite/ fullerene planar layer photovoltaics: improving the efficiency and stability of lead-free devices. J. Mater. Chem. A 3, 1163111640 (2015). https://doi.org/10.1039/C5TA02950C

83. Zhang, M., Lyu, M., Yun, J.H., Noori, M., Zhou, X., Cooling, N.A., Wang, Q., Yu, H., Dastoor, P.C., Wang, L.: Low-temperature processed solar cells with formamidinium tin halide perovskite/fullerene heterojunctions. Nano Res. 9, 1570-1577 (2016). https://doi.org/10.1007/s12274-016-1051-8

84. Krishnamoorthy, T., Ding, H., Yan, C., Leong, W.L., Baikie, T., Zhang, Z., Sherburne, M., Li, S., Asta, M., Mathews, N., Mhaisalkar, S.G.: Lead-free germanium iodide perovskite materials for photovoltaic applications. J. Mater. Chem. A. 3, 23829-23832 (2015). https://doi.org/10.1039/C5TA05741H

85. Cheng, Z., Lin, J.: Layered organic-inorganic hybrid perovskites: structure, optical properties, film preparation, patterning and templating engineering. CrystEngComm 12, 2646 (2010). https://doi.org/10.1039/c001929a

86. Lyu, M., Yun, J.H., Cai, M., Jiao, Y., Bernhardt, P.V., Zhang, M., Wang, Q., Du, A., Wang, H., Liu, G., Wang, L.: 
Organic-inorganic bismuth (III)-based material: a lead-free, air-stable and solution-processable light-absorber beyond organolead perovskites. Nano Res. 9, 692-702 (2016). https ://doi.org/10.1007/s12274-015-0948-y

87. Öz, S., Hebig, J.C., Jung, E., Singh, T., Lepcha, A., Olthof, S., Jan, F., Gao, Y., German, R., van Loosdrecht, P.H.M., Meerholz, K., Kirchartz, T., Mathur, S.: Zero-dimensional $\left(\mathrm{CH}_{3} \mathrm{NH}_{3}\right)_{3} \mathrm{Bi}_{2} \mathrm{I}_{9}$ perovskite for optoelectronic applications. Energy Mater. Sol. Cells, Sol (2015). https://doi.org/10.1016/j. solmat.2016.01.035

88. Kagan, C.R.: Organic-inorganic hybrid materials as semiconducting channels in thin-film field-effect transistors. Science 286, 945-947 (1999). https://doi.org/10.1126/science.286.5441.945

89. Anaya, M., Correa-Baena, J.P., Lozano, G., Saliba, M., Anguita, P., Roose, B., Abate, A., Steiner, U., Grätzel, M., Calvo, M.E., Hagfeldt, A., Míguez, H.: Optical analysis of $\mathrm{CH}_{3} \mathrm{NH}_{3} \mathrm{Sn}_{\mathrm{x}} \mathrm{Pb}_{1-\mathrm{x}} \mathrm{I}_{3}$ absorbers: a roadmap for perovskite-on-perovskite tandem solar cells. J. Mater. Chem. A. 4, 11214-11221 (2016). https://doi. org/10.1039/C6TA04840D

90. Eperon, G.E., Leijtens, T., Bush, K.A., Prasanna, R., Green, T., Wang, J.T.-W., McMeekin, D.P., Volonakis, G., Milot, R.L., May, R., Palmstrom, A., Slotcavage, D.J., Belisle, R.A., Patel, J.B., Parrott, E.S., Sutton, R.J., Ma, W., Moghadam, F., Conings, B., Babayigit, A., Boyen, H.-G., Bent, S., Giustino, F., Herz, L.M., Johnston, M.B., McGehee, M.D., Snaith, H.J.: Perovskite-perovskite tandem photovoltaics with optimized band gaps. Science 354, 861-865 (2016). https://doi.org/10.1126/science.aaf9717

91. Zhao, D., Yu, Y., Wang, C., Liao, W., Shrestha, N., Grice, C.R., Cimaroli, A.J., Guan, L., Ellingson, R.J., Zhu, K., Zhao, X., Xiong, R.-G., Yan, Y.: Low-bandgap mixed tin-lead iodide perovskite absorbers with long carrier lifetimes for all-perovskite tandem solar cells. Nat. Energy. 2, 17018 (2017). https://doi. org/10.1038/nenergy.2017.18

92. Stoumpos, C.C., Malliakas, C.D., Kanatzidis, M.G.: Semiconducting tin and lead iodide perovskites with organic cations: phase transitions, high mobilities, and near-infrared photoluminescent properties. Inorg. Chem. 52, 9019-9038 (2013). https:// doi.org/10.1021/ic401215x

93. Meillaud, F., Shah, A., Droz, C., Vallat-Sauvain, E., Miazza, C.: Efficiency limits for single-junction and tandem solar cells. Sol. Energy Mater. Sol. Cells 90, 2952-2959 (2006). https://doi. org/10.1016/j.solmat.2006.06.002

94. Malinkiewicz, O., Yella, A., Lee, Y.H., Espallargas, G.M.M., Graetzel, M., Nazeeruddin, M.K., Bolink, H.J.: Perovskite solar cells employing organic charge-transport layers. Nat. Photonics 8, 128-132 (2014). https://doi.org/10.1038/nphoton.2013.341

95. Shao, Y., Xiao, Z., Bi, C., Yuan, Y., Huang, J.: Origin and elimination of photocurrent hysteresis by fullerene passivation in $\mathrm{CH}_{3} \mathrm{NH}_{3} \mathrm{PbI}_{3}$ planar heterojunction solar cells. Nat. Commun. 5, 1-7 (2014). https://doi.org/10.1111/j.1365-2230.2009.03702 $\mathrm{x}$

96. Liang, P.W., Liao, C.Y., Chueh, C.C., Zuo, F., Williams, S.T., Xin, X.K., Lin, J., Jen, A.K.Y.: Additive enhanced crystallization of solution-processed perovskite for highly efficient planar-heterojunction solar cells. Adv. Mater. 26, 3748-3754 (2014). https ://doi.org/10.1002/adma.201400231

97. Stoumpos, C.C., Frazer, L., Clark, D.J., Kim, Y.S., Rhim, S.H., Freeman, A.J., Ketterson, J.B., Jang, J.I., Kanatzidis, M.G.: Hybrid germanium iodide perovskite semiconductors: active lone pairs, structural distortions, direct and indirect energy gaps, and strong nonlinear optical properties. J. Am. Chem. Soc. 137, 6804-6819 (2015). https://doi.org/10.1021/Jacs.5b01025

98. Cui, X.P., Jiang, K.J., Huang, J.H., Zhang, Q.Q., Su, M.J., Yang, L.M., Song, Y.L., Zhou, X.Q.: Cupric bromide hybrid perovskite heterojunction solar cells. Synth. Met. 209, 247-250 (2015). https://doi.org/10.1016/j.synthmet.2015.07.013

99. Cortecchia, D., Dewi, H.A., Yin, J., Bruno, A., Chen, S., Baikie, T., Boix, P.P., Grätzel, M., Mhaisalkar, S., Soci, C., Mathews, $\mathrm{N}$.: Lead-free $\mathrm{MA} 2 \mathrm{CuClxBr} 4$-x hybrid perovskites. Inorg. Chem. 55, 1044-1052 (2016). https://doi.org/10.1021/acs.inorg chem.5b01896

100. Liang, K., Mitzi, D.B., Prikas, M.T.: Synthesis and characterization of organic - inorganic perovskite thin films prepared using a versatile two-step dipping technique. Chem. Mater. 10, 403-411 (1998). https://doi.org/10.1021/cm970568f

101. Slavney, A.H., Hu, T., Lindenberg, A.M., Karunadasa, H.I.: A bismuth-halide double perovskite with long carrier recombination lifetime for photovoltaic applications. J. Am. Chem. Soc. 138, 2138-2141 (2016). https://doi.org/10.1021/jacs.5b13294

102. Eckhardt, K., Bon, V., Getzschmann, J., Grothe, J., Wisser, F.M., Kaskel, S.: Crystallographic insights into $\left(\mathrm{CH}_{3} \mathrm{NH}_{3}\right)_{3}\left(\mathrm{Bi}_{2} \mathrm{I}_{9}\right)$ : a new lead-free hybrid organic-inorganic material as a potential absorber for photovoltaics. Chem. Commun. 52, 3058-3060 (2016). https://doi.org/10.1039/C5CC10455F

103. Brandt, R.E., Kurchin, R.C., Hoye, R.L.Z., Poindexter, J.R., Wilson, M.W.B., Sulekar, S., Lenahan, F., Yen, P.X.T., Stevanović, V., Nino, J.C., Bawendi, M.G., Buonassisi, T.: Investigation of bismuth triiodide $\left(\mathrm{BiI}_{3}\right)$ for photovoltaic applications. J. Phys. Chem. Lett. 6, 4297-4302 (2015). https://doi.org/10.1021/acs. jpclett.5b02022

104. Hoye, R.L.Z., Brandt, R.E., Osherov, A., Stevanović, V., Stranks, S.D., Wilson, M.W.B., Kim, H., Akey, A.J., Perkins, J.D., Kurchin, R.C., Poindexter, J.R., Wang, E.N., Bawendi, M.G., Bulović, V., Buonassisi, T.: Methylammonium bismuth iodide as a lead-free, stable hybrid organic-inorganic solar absorber. Chem. A Eur. J. 22, 2605-2610 (2016). https://doi.org/10.1002/ chem. 201505055

Publisher's Note Springer Nature remains neutral with regard to jurisdictional claims in published maps and institutional affiliations. 